\title{
Traffic noise affects forest bird species in a protected tropical forest
}

\author{
J. Edgardo Arévalo ${ }^{1} \&$ Kimberly Newhard ${ }^{1,2}$ \\ 1. The School for Field Studies, Apartado postal 150-4013, Atenas, Alajuela, Costa Rica; earevalo@fieldstudies.org \\ 2. Kimberly Newhard, 5604 Campbell st., Valparaiso, Indiana 46383 USA; kimnewhard@gmail.com
}

\author{
Received 09-VII-2010. Corrected 12-XII-2010. Accepted 12-I-2011.
}

\begin{abstract}
The construction of roads near protected forest areas alters ecosystem function by creating habitat fragmentation and through several direct and indirect negative effects such as increased pollution, animal mortality through collisions, disturbance caused by excessive noise and wind turbulence. Noise in particular may have strong negative effects on animal groups such as frogs and birds, that rely on sound for communication as it can negatively interfere with vocalizations used for territorial defense or courtship. Thus, birds are expected to be less abundant close to the road where noise levels are high. In this study, we examined the effects of road traffic noise levels on forest bird species in a protected tropical forest in Costa Rica. Data collection was conducted in a forest segment of the Carara National Park adjacent to the Coastal Highway. We carried out 120 ten minute bird surveys and measured road noise levels 192 times from the $19^{\text {th }}$ to the $23^{\text {rd }}$ of April and from the $21^{\text {st }}$ to the $28^{\text {th }}$ of November, 2008. To maximize bird detection for the species richness estimates we operated six $12 \mathrm{~m}$ standard mist nets simultaneously with the surveys. The overall mist-netting effort was $240 \mathrm{net} / \mathrm{h}$. In addition, we estimated traffic volumes by tallying the number of vehicles passing by the edge of the park using 24 one hour counts throughout the study. We found that the relative abundance of birds and bird species richness decreased significantly with the increasing traffic noise in the dry and wet season. Noise decreased significantly and in a logarithmic way with distance from the road in both seasons. However, noise levels at any given distance were significantly higher in the dry compared to the wet season. Our results suggest that noise might be an important factor influencing road bird avoidance as measured by species richness and relative abundance. Since the protected forest in question is located in a national park subjected to tourist visitation, these results have conservation as well as management implications. A decrease in bird species richness and bird abundance due to intrusive road noise could negatively affect the use of trails by visitors. Alternatives for noise attenuation in the affected forest area include the enforcement of speed limits and the planting of live barriers. Rev. Biol. Trop. 59 (2): 969-980. Epub 2011 June 01.
\end{abstract}

Key words: bird species richness, bird abundance, bird road avoidance, Carara national park, Costa Rica, noise transmission, traffic volume.

The construction of roads takes up relatively small areas of natural habitats, yet it is responsible for a myriad of negative effects on wild populations (Forman \& Alexander 1998, Trombulak \& Frissell 2000, Coffin 2007, Fahrig \& Rytwinski 2009). Road infrastructure inevitably leads to habitat loss and in most cases the fragmentation of once continuous forests. Roads may therefore represent physical barriers for many species of animals that are not able to move between fragments or that are killed, while crossing the linear gaps produced by roads (Huijser \& Bergers 2000, Hels \& Buchwalds 2001, Clevenger et al. 2003, Kerth $\&$ Melber 2009). This "barrier effect" can be further exacerbated by the type and level of use of road infrastructure. For instance, paved roads and different traffic volumes induce several direct and indirect effects on wildlife populations. Some of the effects include pollution by exhausts, animal mortality, visual disturbance, excessive noise, wind turbulence and ground vibration (Reijnen et al. 1995, Forman \& Alexander 1998, Forman et al. 2002, 
Clevenger et al. 2003, Forman et al. 2003). As a result, animal populations can be isolated due to either the impediment to their movements (e.g. mortality) or their avoidance behavior towards roads (Jaeger et al. 2005).

Organisms that strongly rely on sound for communication seem to be particularly affected by ambient noise (Marten \& Marler 1977). For example, road-derived noise often masks the vocalizations produced by some species of birds whose call frequency overlaps with that of the traffic (Parris \& Schneider 2009). Likewise, it has been argued that the impairment of acoustic signaling by ambient noise may have detrimental effects on the breeding success of some bird species (Reijnen \& Foppen 1994).

Birds exposed to high levels of ambient noise are expected to either adapt their behavior to the competing noise or fail to communicate effectively among their conspecifics due to the masking effect (Brumm 2004, Brumm \& Slater 2006, Fuller et al. 2007, Mockford \& Marshall 2009). For example, Slabbekoorn \& Peet (2003) demonstrated that male Great tits (Parus major) in a noisy environment sang at a higher frequency than individuals singing in a less noisy environment. In contrast, other bird species occur at lower densities near busy roads in an apparent avoidance behavior of the ambient noise (Ferris 1979, Van der Zande et al. 1980, Reijnen et al. 1995, Reijnen et al. 1996).

Although, there has been a recent notable increase in the number of articles that address the effects of trafficked roads on wildlife, the vast majority of those have been conducted in temperate zones (Parris \& Schneider 2009, Fahrig \& Rytwinski 2009, Baskaran \& Boominathan, 2010). The objective of this study is to assess the response of tropical forest bird species towards a trafficked road adjacent to a protected forest in Costa Rica. This study specifically investigates the relationship between bird abundance, species richness and traffic noise. We hypothesize that bird species in a tropical forest would be affected by traffic noise as discussed above. If this were the case, we predict that bird abundance and species richness will be inversely related to road noise. Finally, since the results presented here have conservation as well as management implications, we discuss alternatives for noise attenuation in the affected zone.

\section{MATERIALS AND METHODS}

Study site: Field work was conducted in Carara National Park which is located in the Central Pacific of Costa Rica (9 $46^{\circ} 25.47^{\prime}$ " $\left.\mathrm{N}-84^{\circ} 36^{\prime} 19.90^{\prime \prime} \mathrm{W}\right)$. The park is comprised of 5 242ha which range in elevation was 20-492m above sea level. The main study area is found within the tropical premontane moist forest basal belt transition (Holdridge 1966) and is situated within a narrow belt that varied $24-62 \mathrm{~m}$ in altitude. This type of wet-to-dry transitional forest receives an average of $2800 \mathrm{~mm}$ of rain annually and presents a well defined seasonal pattern. The Western side of the park is bordered by $3.6 \mathrm{~km}$ of one of the busiest and most trafficked roads in Costa Rica: The coastal highway. The average distance from this road to the forest edge was $5 \mathrm{~m}$ with a traffic noise up to 98 decibels at the forest edge (pers. obs.). The study site included three trail loop systems in the park with a variable range of distances from the road. The "close" location in both the Universal and Araceas Trails (UT and AT) consisted of two separate loops, whereas the Quebrada Bonita Trail (QBT) consisted of a single loop in the "far" location. Sixteen permanent point counts for bird surveys were established; eight on each trail location (see species richness section below). We observed no major apparent differences in forest structure (e.g. presence of forest gaps) surrounding the point counts placed along the trail.

Species richness, bird abundance and road noise: We conducted bird surveys in the 16 permanent sample points, numbered from one to eight at each "close" and "far" trail location, using the point count technique (Ralph et al. 1995). Bird surveys were conducted from the $19^{\text {th }}$ to the $23^{\text {rd }}$ of April and from the $21^{\text {st }}$ 
to the $28^{\text {th }}$ of November, 2008. The April sampling period corresponds to the late dry season and November sampling to the late wet season. Although the number of days in the field was different in the two working periods, the effective sampling effort was the same for both wet and dry seasons. Though we did record some species which are commonly associated to edges or open areas, the vast majority of the species in this study showed a degree of forest dependence (Stiles \& Skutch 1989, pers. obs.). We established the first permanent point at one end of each trail system and then placed seven more every $120 \mathrm{~m}$ along each trail (except from plot four and five in UT and AT that were $370 \mathrm{~m}$ apart). The points along the UT and AT ranged between $74-284 \mathrm{~m}$ from the road and between $483-666 \mathrm{~m}$ in the QBT. The distances between each point count and the road were obtained using a portable GPS (Magellan eXplorist 500) and the Google Earth application.

We carried out two daily surveys from 06:00 to $08: 00 \mathrm{~h}$ and from 14:00 to $16: 00 \mathrm{~h}$. The surveys were conducted by one experienced ornithologist accompanied by thee assistants at both trail locations. We alternated the order of the starting sequence of the surveys from point one to eight and from point eight to one to homogenize bird activity in time and conducted the same number of surveys in the morning and in the afternoon on each trail. All birds seen or heard within a $30 \mathrm{~m}$ radius were counted and identified to species within a $10 \mathrm{~min}$ sampling period. To minimize counting individuals more than once, we noted the directions that the birds were moving and recorded only once the birds that were out of sight but were heard (unless it was certain that two individuals were calling simultaneously). To complement the point counts for the overall assessment of species richness at the two site locations, we operated six $12 \mathrm{~m}$ standard mist nets simultaneously with the surveys from 06:00 to 10:00h and from 14:00 to 16:00h at each of the AT and QBT trails. We sampled the same locations during the dry and the wet seasons. The mist-netting point on the AT was $91.6 \mathrm{~m}$ and the QBT point was $560.6 \mathrm{~m}$ from the road. Mist nets were checked every $20 \mathrm{~min}$ and the trapped birds were handled following the standard protocol (the main researcher has a formal mist netting training). To avoid counting individuals more than once we marked the birds by clipping the tip of a secondary wing feather or by using color bands. The overall mist-netting effort was 240net/h. Since we were not mist-netting and surveying birds at each of the counting points simultaneously, we used only visual and sound records to estimate the relative abundance. This was calculated by dividing the total number of individuals counted by the number of times each point was surveyed within the detectable radius and then averaged by the total point counts.

Although we are aware that both the abundance of birds and species richness are strongly correlated, we did not use any diversity index since this approach would be strongly influenced and biased by the sampling method we used. In addition, we believe that the use of the direct dependent variables (species richness and abundance) would yield practical and complementary information for management purposes.

Road noise: To investigate a potential relationship between bird abundance and richness and road noise, we measured ambient noise in decibels $(\mathrm{dB})$ with a digital sound meter (Extech 407730 Digital Sound Level Meter) at each of the bird counting points. We held the sound meter at $1.2 \mathrm{~m}$ above the ground, always aiming towards the road and set in the fast (A/C) data recording mode. To calculate average ambient noise at each of the bird counting points, we took ten noise measurements every min both in the morning and in the afternoon during the length of the sampling period (noise measurements affected by thunder and overflying helicopters were not included). Sample sizes between seasons are different because we omitted two sampling points that were close to a stream that significantly increased noise only in the wet season due to heavy rains.

Traffic volume: Since noise levels are determined by the traffic volumes on the 
Coastal Highway we tallied passing vehicles at different times of the day ranging from 07:00 to $16: 00 \mathrm{~h}$ and at intervals of one, ten and $60 \mathrm{~min}$. Interpolation and extrapolation of the numbers of vehicles counted in one hour, one or $10 \mathrm{~min}$ bouts yielded very similar results. This suggests a constant traffic flow throughout the study period. Thus, for the purpose of the current investigation we present traffic volume as vehicles/h. Counts of vehicles were conducted twice a day in a simultaneous manner with the bird surveys. Because the size of the vehicles may influence the level of noise produced, an observer classified passing vehicles as either light or heavy using two different manual counters. Light vehicles included motorcycles, cars, small trucks and vans whereas the heavy category included medium to large size trucks, buses and trailers.

Analyses: We used mist nets and bird counts to assess the overall species richness and abundance in both "close" and "far" locations. Since we had only a single mist-netting point per location where we did not visually surveyed birds, only point count data were used for the regression analyses between the independent variables (noise) and the response variables (species richness and abundance). Analyses were kept separately by season because noise levels were significantly different between them.

For noise transmission we fit logarithmic lines for the regressions between noise and distance to show noise attenuation as it propagated through the forest. Differences in the overall levels of noise between UAT and QBT in both the dry and the wet seasons were compared with non parametric Kruskal-Wallis test.

We measured noise and distance to be used as independent variables that could explain changes in bird abundance and bird species richness. However, these two independent variables were strongly correlated with one another $(\mathrm{r}=-0.76, \mathrm{n}=16, \mathrm{p}=0.0007$ for the dry season and $\mathrm{r}=-0.75, \mathrm{n}=14, \mathrm{p}=0.002$ for the wet season) thus presenting collinearity, a situation that could reduce statistical power in a multiple regression model (Graham 2003). This was indeed the case in our exploratory analysis. Since a handful of traffic emissions (including noise) decrease with distance from the road, it is likely to expect that most of such emissions would be correlated inversely with distance. With these considerations we regard noise, rather than distance per se, as the most adequate predictor and the most parsimonious approach to explain changes in bird abundance and species richness. We use an analysis of covariance to test the effects of seasons as factors and noise as a covariate on the above mentioned dependent variables.

\section{RESULTS}

Species richness, bird abundance and road noise: Overall, we recorded a total of 129 species of birds during the entire study (Appendix 1 for the species list), with 89 species recorded in the "close" trail compared to 97 in the "far" trail site. The relative bird abundance was also higher in the "far" $(8.11 \pm 2.87)$ compared to the "close" $(5.7 \pm 2.39)$ site (Wilcoxon test, $\mathrm{p}=0.02$ ).

The relative abundance of birds decreased significantly with the increasing road noise in both the dry and the wet season (ANCOVA, $\mathrm{F}_{1,30}=6.30, \mathrm{p}=0.018$, Fig. 1). Likewise, species richness significantly decreased with road noise both in the dry and the wet seasons (ANCOVA, $\mathrm{F}_{1,30}=9.84, \mathrm{p}=0.0041$, Fig. 2). Also, birds were more abundant in the dry than in the wet season (ANCOVA, $\mathrm{F}_{1,30}=35.16, \mathrm{p}<0.0001$, Fig. 1). A similar pattern was found for changes in species richness in the two seasons (ANCOVA, $\mathrm{F}_{1,30}=44.78, \mathrm{p}<0.0001$, Fig. 2).

Road noise: Levels of ambient noise were higher in the UAT than in the QBT both within and between seasons (Kruskal-Wallis test, $\left.\chi^{2}=20.9, \mathrm{DF}=3, \mathrm{p}=0.0001\right)$. Noise level decreased significantly and in a logarithmic way both in the wet $\left(\mathrm{r}^{2}=0.59, \mathrm{n}=14, \mathrm{p}=0.001\right)$ and in the dry season $\left(\mathrm{r}^{2}=0.56, \mathrm{n}=16, \mathrm{p}=0.0008\right)$. The transmission of ambient noise from the road towards the inner forest was attenuated at a 




Fig. 1. Relative abundance of birds as a function of ambient noise produced by the Coastal Highway that borders Carara National Park. Filled circles and dashed line represent the relationship for the wet season and the open circles and solid line for the dry season, 2008.

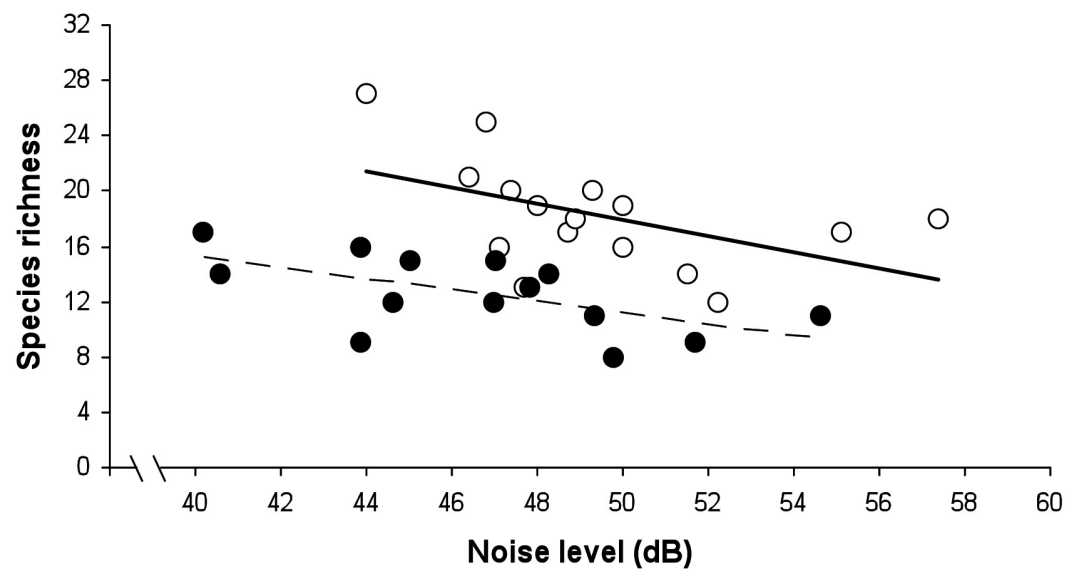

Fig. 2. Species richness of birds as a function of ambient noise produced by the Coastal Highway that borders Carara National Park. Filled circles and dashed line represent the relationship for the wet season and the open circles and solid line for the dry season, 2008.

faster rate in the wet season compared with the dry season (Fig. 3). In addition, levels of noise were higher at any given distance in the dry compared to those in the wet season (Fig. 3).

Traffic volume: Traffic volume recorded in the dry season was higher than in the wet season, but due mostly to differences in light vehicles. The mean vehicles per hour for light cars in the dry season was $332.7( \pm 112.4)$ compared to $308.7( \pm 116.4)$ in the wet season. The mean for heavy vehicles per hour in the dry season was $62.0( \pm 21.4)$ and $57.6( \pm 18.8)$ for the wet season. These two categories of vehicles sum a total average of 394.7 and 366.3 for the dry and the wet season respectively.

A conservative estimate based on the observed traffic volume would range between 5000-6000 cars per day, $16 \%$ comprising heavy vehicles, which tend to be noisier than 


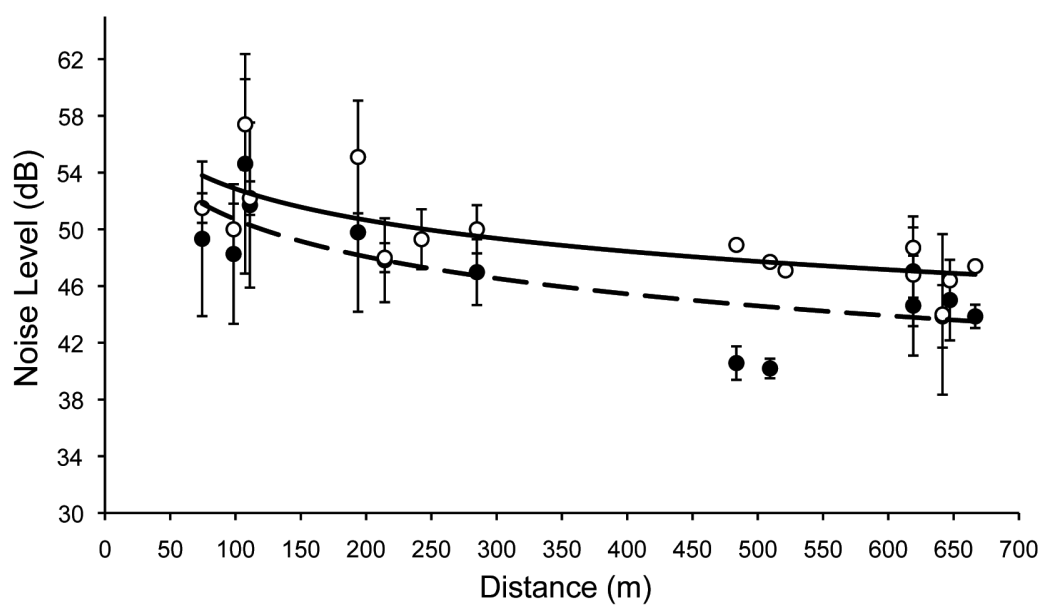

Fig. 3. Noise transmission through the forest as a function of the distance from the Coastal Highway that borders Carara National Park. Filled circles and dashed line for the wet season and open circles and solid line for the dry season, 2008.

light vehicles. Nonetheless, it is likely that this volume could reach up to 10000 cars on busy days (pers. obs.)

\section{DISCUSSION}

As a general pattern, we recorded more species and higher abundance of birds in the "far" trail than in the "close" trail site. These results are in agreement with the general and expected pattern attributed to the negative road effects on animals reported in the literature (Forman et al. 2003, Coffin 2007, Fahrig \& Rytwinski 2009). A reduction in the number of birds near trafficked roads does not necessarily mean that the birds avoid the affected zone as a result of behavioral responses (Jaeger et al. 2005, Fahrig \& Rytwinski 2009). Bird species that do not avoid trafficked roads can suffer mortality because of car collisions thereby reducing their abundance near roads (Jaeger et al. 2005). However, a recent study on road mortality in a tropical forest bisected by a road showed that birds make only $7 \%$ of all the vertebrate road kills (Baskaran \& Boominathan 2010). Road mortality does not seem to be an important cause affecting bird abundance in our study area. This is because several species of forest interior birds do not frequently cross the road as there are pastures and very little tree cover on the opposite side of the park (per. obs.). In addition, most flying birds are very maneuverable and it is possible that birds may learn to avoid collisions as they experience and interact with traffic (e.g. Mumme et al. 2000). Therefore, it seems unlikely that road mortality has significantly influenced the reduction of the abundance and species richness of birds in the present study. Alternatively, it has been suggested that birds can avoid areas adjacent to roads either because of the low quality of territories (Reijnen \& Foppen 1994, Ortega \& Capen 1999) or due to car emissions such as exhaust pollution, ground vibrations, visual stimuli and noise (Forman \& Alexander 1998, Forman et al. 2003). The multiple abiotic and biotic effects of heterogeneous forest edges along roads also affect abundance, richness and composition of bird species (Murcia 1995, Ries et al. 2004). These multiple interacting factors make it very difficult to disentangle the effects caused by traffic emissions from edge effects per se. Nonetheless, both the characteristics of the study site and the sampling design used minimized the potential confounding effects of the forest edge. First, the road adjacent to the 
forest in Carara National Park and its associated edge has 38 years of existence. Thus, there have been several generations of birds that have interacted and possible habituated to the edge conditions. Second, none of the bird point count locations was situated at the forest edge; $74 \mathrm{~m}$ from the road being the minimum distance of the nearest point. Although there is no consensus as to the penetration distance of the edge-derived disturbances, it is proposed that some effects could reach between 50 to $200 \mathrm{~m}$ towards the inner forest (Ries et al. 2004). It is reasonable to think that the magnitude of such effects tend to decrease with distance from the edge. Consequently, the influence of edge effects on bird abundance and richness in the present study can be assumed to be negligible. In contrast, an increase in traffic noise emission might be expected to be a more recent disturbance associated to an increased in the number of vehicles in Costa Rica, particularly in the last decade (González et al. 2007). Noise is regarded as one the most negative and pervasive effects of all road disturbances (Forman \& Alexander 1998, Forman et al. 2003, Coffin 2007). For example, Reijnen et al. (1995) found no effect of the visual stimulus on bird distribution, while keeping constant the levels of noise. However, bird distribution was negatively correlated with noise when the visual stimulus of cars on the highway was kept constant. The investigation concluded that the visual disturbance affected only a short distance from the road, while traffic noise extended much farther, thus strongly affecting bird density. Also, Bayne et al. (2008) showed that density of passerine bird species was 1.5 times higher in noiseless areas compared to the one in places where chronic noise generated by energy facility machinery was present. This suggests that noise per se rather than other road-derived effects can significantly induce bird avoidance hence a reduction in local abundance.

Our results support the hypothesis that noise from the road was an important factor affecting bird abundance and species richness in Carara National Park. Both bird abundance and species richness were inversely associated with noise in a consistent and significant manner in the two seasons (Fig. 1, 2). However, bird abundance and noise were only weakly associated in the dry season as compared with the wet season for which this relationship was stronger (Fig. 1). It is difficult to interpret this apparent discrepancy, though it could be attributed to differences in the species composition and bird abundances between seasons. We registered a difference of 245 individuals and eleven species more in the dry compared with the wet season. Also, 37 species out of 103 recorded in the dry season were not registered in the wet season (35\%); and 22 from 92 species detected in the wet season were not recorded in the dry season (23\%). It is then possible that some species recorded in the dry season were not sensitive enough to noise disturbance, hence affecting the strength of the relationship between bird abundance and noise. Another plausible explanation might be that some birds became habituated to the noise that prevailed during the dry season. This might seem paradoxically, since average noise levels at the counting points remained somewhat louder in the dry compared to the wet season (Fig. 3). However, the noise gradient in the dry season was less pronounced compared to that of the wet season (Fig. 3). Thus, birds in the wet season may have had a noise aversion induced response, rather than an habituation response, based on the fact that there was a more pronounced gradient in noise levels. This noise gradient could be due to rapid attenuation by the forest during the wet season when the foliage is denser than that in the dry season. Behavioral responses to noise emissions by animals are expected to change depending on habitat structure, traffic volume, time of the day and season. Therefore, measuring the "road-zone effect" might be complex and difficult but the effects by virtue of road proximity alone are thought to be of great magnitude (Coffin 2007).

Management implications: The results presented here urge decision making actions to ameliorate current and future negative effects in the affected zone of Carara National Park. 
In particular, special attention needs to be paid to the newly opened road that connects the capital, San José, with the Coastal highway which leads to various popular beaches. Traffic volume on this new road reached 2000 cars per hour on the inauguration day, and similar volumes are expected during national holidays. Although, there were a few more light vehicles possibly augmenting noise in the dry compared to the wet season, the denser and wetter foliage in the wet season could have played an important role in the pronounced attenuation of the noise (Fig. 3). This has important implications for future noise impacts in the national park since traffic volumes are expected to increase in the dry season when most tourist swarm the nearby beaches. Strategies to mitigate noise and reduce road mortality have been proposed (e.g. Van der Ree et al. 2009), however, they are often costly and not feasible to implement for developing countries like Costa Rica. We believe that one cost-effective and feasible strategy is the implementation and enforcement of the speed limits in vehicles. It has been shown that slow traffic reduces noise and could definitively minimize road kills (Van Langevelde et al. 2009). Another strategy is to place live barriers that can attenuate noise that would reduce the intensity of noise in the inner forest (Slabbekoorn \& Ripmeester 2008). It is noteworthy to mention that Carara National Park receives over 33000 visitors annually, and that the great majority uses the limited number of trails, including the ones where the noise is greatest. Implementing immediate actions to mitigate noise disturbances would enhance the conservation of bird species and biodiversity in general. In addition, noise reduction would maximize the enjoyment of visitors which in turn may generate more revenues to the park.

\section{ACKNOWLEDGMENT}

We would like to thank Adrian Arce and José Badilla of Carara National Park for their collaboration with this study. Andrés Jiménez, Nancy Orias, Marcello Araya and Andrés Camacho assisted in the bird surveys. Thanks to the students Michael Ambrogi, Trina Campbell, Miranda Carter, Kristine Dennis, Ariela Haber, Sarah Feinman, Nora Kaufmann, Gordon Kersten, Kara Malone, Elizabeth Ransey, Ashton Rohmer, Chistianne Shinskie, Mike Soike and Gabriella Sterne of the School for Field Studies (Spring and Fall 2008) who collaborated during data collection. Gerardo Avalos, Gilbert Barrantes and Federico Bolaños provided general advice in data analyses. We are grateful to Dan Chamberlain, Richard Ladle, Robin Sears and two anonymous reviewers for their comments on the manuscript. The authors gratefully acknowlege the key financial and logistical support provided by The School for Field Studies.

\section{RESUMEN}

Las carreteras cerca de bosques alteran la función del ecosistema por fragmentación del hábitat y tienen otros efectos negativos como contaminación, mortalidad de animales y ruido excesivo; sobre todo en animales como ranas y aves que dependen del sonido para comunicarse. Se espera menos abundancia de aves cerca de la carretera donde el ruido es alto. Este estudio evalúa los efectos del ruido por carretera sobre las aves en un bosque tropical de Costa Rica. También realizamos censos de aves y medimos el ruido del 19 al 23 de abril y del 21 al 28 de noviembre 2008. Además, utilizamos redes de niebla para maximizar la detección de aves en la estimación de riqueza de especies. La abundancia de aves así como la riqueza de especies decrecieron significativamente con el incremento del ruido tanto en la estación seca como en la lluviosa. El ruido disminuyó en forma logarítmica con el aumento en la distancia a la carretera y fue más alto durante la estación seca. Nuestros resultados sugieren que las aves tienden generalmente a evitar el ruido del tráfico y tienen implicaciones en la conservación y manejo del área protegida.

Palabras clave: abundancia de aves, atenuación del ruido, Costa Rica, evasión de calles por aves, parque nacional Carara, riqueza de especies de aves, transmisión del ruido, volumen vehicular.

\section{REFERENCES}

Baskaran, N. \& D. Boominathan. 2010. Road kill of animals by highway traffic in the tropical forest of Mudumalai Tiger Reserve Southern India. J. Theat. Taxa 2: 753-759. 
Bayne, E.M., L. Habib \& S. Boutin. 2008. Impacts of chonic anthopogenic noise from energy-sector activity on abundance of songbirds in the Boreal Forest. Conserv. Biol. 22: 1186-1193.

Brumm, H. 2004. The impact of environmental noise on song amplitude in a territorial bird. J. Anim. Ecol. 73: 434-440.

Brumm, H. \& P.J.B. Slater. 2006. Ambient noise, motor fatigue and serial redundancy in chaffinch song. Behav. Ecol. Sociobiol. 60: 475-481.

Clevenger, A.P., B. Chuszcz \& K.E. Gunson. 2003. Spatial patterns and factors influencing small vertebrate fauna road-kill aggregations. Biol. Conserv. 109: 15-26.

Coffin, A.W. 2007. From roadkill to road ecology: A review of the ecological effects of roads. J. Transp. Geogr. 15: 396-406.

Fahrig, L. \& T. Rytwinski. 2009. Effects of roads on animal abundance: An empirical review and synthesis. Ecol. Soc. 14: 21.

Ferris, C.R. 1979. Effects of Interstate 95 on breeding birds in northern Maine. J. Wildlife Manage. 43: 421-427.

Forman, R.T.T. \& L.E. Alexander. 1998. Roads and their major ecological effects. Annu. Rev. Ecol. Syst. 29: 207-231.

Forman, R.T.T., B. Reineking \& A.M. Hersperger. 2002. Road traffic and nearby grassland bird patterns in a suburbanizing landscape. Environ. Manage. 29: $782-800$.

Forman, R.T.T., D. Sperling, J. Bissonette, A. Clevenger, C. Cutshall, V. Dale, L. Fahrig, R. France, C. Goldman, K. Heanue, J. Jones, F. Swanson, T. Turrentine \& T. Winter. 2003. Road ecology: science and solutions. Island, Washington D.C., USA.

Fuller, R.A., P.H. Warren \& K.J. Gaston. 2007. Daytime noise predicts nocturnal singing in urban robins. Biol. Lett. 3: 368-370.

González, C., P.C. Fernández \& V.M. Salazar. 2007. Anuario estadístico del sector transporte. Capítulo II. Dirección de planificación sectorial, Ministerio de Obras Públicas, San José, Costa Rica (también disponible en línea www.mopt.go.cr/planificacion/ estadisticas/Anuario07.pdf).

Graham, M.H. 2003. Confronting multicollinearity in ecological multiple regression. Ecology 84: 2809-2815.
Hels, T. \& E. Buchwalds 2001. The effect of road kills on amphibian populations. Biol. Conserv. 99: 331-340.

Holdridge, L.R. 1966. The life zone system. Adansonia 6: 199-203.

Huijser, M.P. \& P.J.M. Bergers. 2000. The effect of roads and traffic on hedgehog (Erinaceus europaeus) populations. Biol. Conserv. 95: 111-116.

Jaeger, J.A.G., J. Bowman, J. Brennan, L. Fahrig, D. Bert, J. Bouchard, N. Charbonneau, K. Frank, B. Gruber \& K.T. von Toschanowitz. 2005. Predicting when animal populations are at risk from roads: an interactive model of road avoidance behavior. Ecol. Model. 185: 329-348.

Kerth, G. \& M. Melber. 2009. Species-specific barrier effects of a motorway on the habitat use of two theatened bat species. Biol. Conserv. 142: 270-279.

Marten, K. \& P. Marler. 1977. Sound transmission and its significance for animal vocalization: I. Temperate habitats. Behav. Ecol. Sociobiol. 2: 271-290.

Mockford, E.J. \& R.C. Marshall. 2009. Effect of urban noise on song and response behaviour in great tits. P. Roy. Soc. B-Biol. Sci. 279: 2979-2985.

Mumme, R.L, S.J. Schoech, G.E. Woolfenden \& J.W. Fitzpatrick. 2000. Life and death in the fast lane: Demographic consequences of road mortality in the Florida Scrub-Jay. Conserv. Biol. 14: 501-512.

Murcia, C. 1995. Edge effects in fragmented forests: implications for conservations. Trends Ecol. Evol. 10: $58-62$.

Ortega, Y.K. \& D.E. Capen. 1999. Effects of forest roads on habitat quality for ovenbirds in a forested landscape. Auk 116: 937-946.

Parris, K.M. \& A. Schneider. 2009. Impacts of traffic noise and traffic volume on birds in roadside habitats. Ecol. Soc. 14: 29.

Ralph, C.J., S. Droege \& J.R. Sauer. 1995. Managing and monitoring birds using point counts: standards applications, p. 161-168. In C.J. Ralph, J. Sauer \& S. Droege (eds.). Monitoring bird populations by point counts. PSW-GTR-149. USDA Forest Service, Pacific Southwest Research Station, Albany, California.

Reijnen, R. \& R. Foppen. 1994. The effects of car traffic on breeding bird populations in woodland. I. Evidence of reduced habitat quality for willow warblers (Phylloscopus trochilus) breeding close to a highway. J. Appl. Ecol. 31: 85-94. 
Reijnen, R., R. Foppen, C. ter Braak \& J. Thissen. 1995. The effects of car traffic on breeding bird populations in woodland. III. Reduction of density in relation to the proximity of main roads. J. Appl. Ecol. 32: 187-202.

Reijnen, R., R. Foppen \& H. Meeuwsen. 1996. The effect of traffic on the density of breeding birds in Dutch agricultural grasslands. Biol. Conserv. 75: 255-260.

Ries, L., R.J. Fletcher Jr., J. Battin \& T.D. Sisk. 2004. Ecological responses to habitat edges: Mechanisms, models, and variability explained. Annu. Rev. Ecol. Evo. S. 35: 491-522.

Slabbekoorn, H. \& M. Peet. 2003. Ecology: Birds sing at a higher pitch in an urban noise. Nature 424: 267.

Slabbekoorn, H. \& E.A.P. Ripmeester. 2008. Birdsong and anthopogenic noise: Implications and applications for conservation. Mol. Ecol. 17: 72-83.
Stiles, F.G. \& A.F. Skutch. 1989. A Guide to the Birds of Costa Rica. Cornell University, Ithaca, New York, USA.

Trombulak, S.C. \& C.A. Frissell. 2000. Review of ecological effects of roads on terrestrial and aquatic communities. Conserv. Biol. 14: 18-30.

Van der Ree, R., D. Heinze, M. McCarthy \& I. Mansergh. 2009. Wildlife tunnel enhances population viability. Ecol. Soc. 14: 7.

Van der Zande, A.N., W.J. ter Keurs \& W.J. van der Weijden. 1980. The impacts of roads on the densities of four bird species in an open field habitat - evidence of a long-distance effect. Biol. Conserv. 18: 299-321.

Van Langevelde, F., C. Van Dooremalen \& C.F. Jaarsma. 2009. Traffic mortality and the role of minor roads. J. Environ. Manage. 90: 660-667. 
APPENDIX I

List of bird species recorded in the study site, Carara National Park, Costa Rica

\begin{tabular}{|c|c|c|c|c|c|c|c|}
\hline Scientific Name & NM & $\mathrm{R}$ & $\mathrm{R}, \mathrm{NM}$ & Scientific Name & NM & $\mathrm{R}$ & $\mathrm{R}, \mathrm{NM}$ \\
\hline Amazilia decora & & $\mathrm{X}$ & & Glyphorhynchus spirurus & & $\mathrm{X}$ & \\
\hline Amazilia rutila & & $\mathrm{X}$ & & Gymnopithys leucaspis & & $\mathrm{X}$ & \\
\hline Amazilia saucerrottei & & $\mathrm{X}$ & & Hylocharis eliciae & & $\mathrm{X}$ & \\
\hline Amazilia tzacatl & & $\mathrm{X}$ & & Hylocichla mustelina & $\mathrm{X}$ & & \\
\hline Amazona auropalliata & & $\mathrm{X}$ & & Hyloctistes subulatus & & $\mathrm{X}$ & \\
\hline Amazona autumnalis & & $\mathrm{X}$ & & Hylopezus perspicillatus & & $\mathrm{X}$ & \\
\hline Amazona farinosa & & $\mathrm{X}$ & & Hylophilus decurtatus & & $\mathrm{X}$ & \\
\hline Anthacothorax prevostii & & $\mathrm{X}$ & & Hylophilus ochaceiceps & & $\mathrm{X}$ & \\
\hline Ara macao & & $\mathrm{X}$ & & Lepidocolaptes souleyetii & & $\mathrm{X}$ & \\
\hline Aratinga finschi & & $\mathrm{X}$ & & Leptotila verreauxi & & $\mathrm{X}$ & \\
\hline Arremon aurantiirostris & & $\mathrm{X}$ & & Lipaugus unirufus & & $\mathrm{X}$ & \\
\hline Attila spadiceus & & $\mathrm{X}$ & & Malacoptila panamensis & & $\mathrm{X}$ & \\
\hline Automolus ocholaemus & & $\mathrm{X}$ & & Manacus aurantiacus & & $\mathrm{X}$ & \\
\hline Basileuterus rufifrons & & $\mathrm{X}$ & & Micrastur semitorquatus & & $\mathrm{X}$ & \\
\hline Brotogeris jugularis & & $\mathrm{X}$ & & Microcerculus marginatus & & $\mathrm{X}$ & \\
\hline Campephilus guatemalensis & & $\mathrm{X}$ & & Microrhopias quixensis & & $\mathrm{X}$ & \\
\hline Campylorhynchus rufinucha & & $\mathrm{X}$ & & Mionectes oleagineus & & $\mathrm{X}$ & \\
\hline Catharus ustulatus & $\mathrm{X}$ & & & Mniotilta varia & $\mathrm{X}$ & & \\
\hline Cercomacra tyrannina & & $\mathrm{X}$ & & Momotus momota & & $\mathrm{X}$ & \\
\hline Ceryle alcyon & $\mathrm{X}$ & & & Morococcyx erythopygius & & $\mathrm{X}$ & \\
\hline Chiroxiphia linearis & & $\mathrm{X}$ & & Myiarchus tuberculifer & & $\mathrm{X}$ & \\
\hline Contopus cinereus & $\mathrm{X}$ & & & Myiarchus tyrannulus & & $\mathrm{X}$ & \\
\hline Contopus sordidulus & $X$ & & & Myiobius sulphureipygius & & $\mathrm{X}$ & \\
\hline Contopus virens & $\mathrm{X}$ & & & Myiodynastes maculatus & & $\mathrm{X}$ & \\
\hline Crax rubra & & $\mathrm{X}$ & & Myiozetetes granadensis & & $\mathrm{X}$ & \\
\hline Crypturellus soui & & $\mathrm{X}$ & & Myiozetetes similis & & $\mathrm{X}$ & \\
\hline Cyanerpes cyaneus & & $\mathrm{X}$ & & Myrmeciza exsul & & $\mathrm{X}$ & \\
\hline Cyanerpes lucidus & & $\mathrm{X}$ & & Myrmotherula schisticolor & & $\mathrm{X}$ & \\
\hline Cyanocompsa cyanoides & & & $\mathrm{X}$ & Oncostoma cinereigulare & & $\mathrm{X}$ & \\
\hline Cyanocorax morio & & $\mathrm{X}$ & & Onychorhynchus coronatus & & $\mathrm{X}$ & \\
\hline Cyclarhis gujanensis & & $\mathrm{X}$ & & Pachyramphus aglaiae & & $\mathrm{X}$ & \\
\hline Dacnis cayana & & $\mathrm{X}$ & & Pachyramphus polychopterus & & $\mathrm{X}$ & \\
\hline Dendrocincla anabatina & & $\mathrm{X}$ & & Patagioenas nigrirostris & & $\mathrm{X}$ & \\
\hline Dendrocolaptes sanctithomae & & $\mathrm{X}$ & & Penelope purpurascens & & $\mathrm{X}$ & \\
\hline Dendroica fusca & $\mathrm{X}$ & & & Phaethornis longirostris & & $\mathrm{X}$ & \\
\hline Dendroica pensylvanica & $\mathrm{X}$ & & & Phaethornis striigularis & & $\mathrm{X}$ & \\
\hline Dryocopus lineatus & & $\mathrm{X}$ & & Piaya cayana & & $\mathrm{X}$ & \\
\hline Empidonax virescens & $\mathrm{X}$ & & & Pionus senilis & & $\mathrm{X}$ & \\
\hline Eucometis penicillata & & $\mathrm{X}$ & & Pipra coronata & & $\mathrm{X}$ & \\
\hline Eudocimus albus & & $\mathrm{X}$ & & Pipra mentalis & & $\mathrm{X}$ & \\
\hline Euphonia hirundinacea & & $\mathrm{X}$ & & Piranga rubra & $\mathrm{X}$ & & \\
\hline Euphonia imitans & & $\mathrm{X}$ & & Pitangus sulphuratus & & $\mathrm{X}$ & \\
\hline Formicarius analis & & $\mathrm{X}$ & & Platyrinchus cancrominus & & $\mathrm{X}$ & \\
\hline Geotrygon montana & & $\mathrm{X}$ & & Platyrinchus coronatus & & $\mathrm{X}$ & \\
\hline
\end{tabular}


APPENDIX I (Continued)

List of bird species recorded in the study site, Carara National Park, Costa Rica

\begin{tabular}{|c|c|c|c|c|c|c|c|}
\hline Scientific Name & NM & $\mathrm{R}$ & $\mathrm{R}, \mathrm{NM}$ & Scientific Name & NM & $\mathrm{R}$ & $\mathrm{R}, \mathrm{NM}$ \\
\hline Polioptila plumbea & & $\mathrm{X}$ & & Thyothorus rutilus & & $\mathrm{X}$ & \\
\hline Pteroglossus frantzii & & $\mathrm{X}$ & & Thyothorus semibadius & & $\mathrm{X}$ & \\
\hline Ramphastos swainsonii & & $\mathrm{X}$ & & Tinamus major & & $\mathrm{X}$ & \\
\hline Rhynchocyclus brevirostris & & $\mathrm{X}$ & & Tityra semifasciata & & $\mathrm{X}$ & \\
\hline Rhytipterna holerytha & & $\mathrm{X}$ & & Todirostrum cinereum & & $\mathrm{X}$ & \\
\hline Saltator maximus & & $\mathrm{X}$ & & Tolmomyias sulphurescens & & $\mathrm{X}$ & \\
\hline Sarcoramphus papa & & $\mathrm{X}$ & & Trogon bairdii & & $\mathrm{X}$ & \\
\hline Schiffornis turdinus & & $\mathrm{X}$ & & Trogon massena & & $\mathrm{X}$ & \\
\hline Seiurus noveboracensis & $\mathrm{X}$ & & & Trogon rufus & & $\mathrm{X}$ & \\
\hline Sittasomus griseicapillus & & $\mathrm{X}$ & & Trogon violaceus & & $\mathrm{X}$ & \\
\hline Sporophilia aurita & & $\mathrm{X}$ & & Turdus grayi & & $\mathrm{X}$ & \\
\hline Tachyphonus luctuosus & & $\mathrm{X}$ & & Vermivora peregrina & $\mathrm{X}$ & & \\
\hline Tangara gyrola & & $\mathrm{X}$ & & Vireo flavoviridis & & & $\mathrm{X}$ \\
\hline Tangara larvata & & $\mathrm{X}$ & & Vireolanius pulchellus & & $\mathrm{X}$ & \\
\hline Terenotriccus erythurus & & $\mathrm{X}$ & & Wilsonia pusilla & $\mathrm{X}$ & & \\
\hline Thamnophilus bridgesi & & $\mathrm{X}$ & & Xenops minutus & & $\mathrm{X}$ & \\
\hline Thamnophilus doliatus & & $\mathrm{X}$ & & Xiphorhynchus erythopygius & & $\mathrm{X}$ & \\
\hline Thenetes ruckeri & & $\mathrm{X}$ & & Xiphorhynchus lachymosus & & $\mathrm{X}$ & \\
\hline Thyothorus fasciatoventris & & $\mathrm{X}$ & & Xiphorhynchus susurrans & & $\mathrm{X}$ & \\
\hline Thyothorus modestus & & $\mathrm{X}$ & & Zimmerius vilissimus & & $\mathrm{X}$ & \\
\hline Thyothorus rufalbus & & $\mathrm{X}$ & & & & & \\
\hline
\end{tabular}

Scientific names according to the updated official list of birds of Costa Rica, Obando-Calderón et al. 2009 (http:// avesdecostarica.org/listas.htm). NM=Neotropical Migrant, R=Resident, R-NM=Populations with both residents and migrants. 